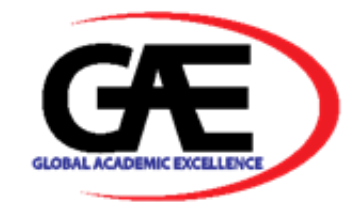

\title{
SPEED AND ACCURACY OF EXAMINATION OF BRANDS VERY IMPORTANT IN LEGAL CERTAINTY FOR BRAND REGISTERS IN INDONESIA
}

\author{
Yusuf Gunawan ${ }^{1}$ \\ 1 Doctor of Law Program, Universitas Jayabaya, Indonesia \\ Email: essensiajkt@gmail.com
}

\section{Article Info:}

\section{Article history:}

Received date: 01.08.2020

Revised date: 15.08 .2020

Accepted date: 10.01.2021

Published date: 05.03.2021

\section{To cite this document:}

Gunawan, Y. (2021). Speed and Accuracy of Examination of Brands Very Important in Legal Certainty for Brand Registers in Indonesia. International Journal of Law, Government and Communication, 6 (22), 45-55.

DOI: $10.35631 /$ IJLGC.622004.

This work is licensed under CC BY 4.0

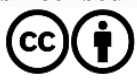

\begin{abstract}
:
A brand is a form of intellectual property right that has a very important role and value for the smooth and increasing trade in goods or services. Thus the importance of the role of this brand, then the brand put legal protection. The long process when the brand registration in Indonesia is detrimental to the business world in global competition. This research is to find out and review the implementation of the brand registration process in Indonesia in an effort to speed up and appropriately check a brand in order to obtain legal certainty. Another goal is to find solutions to problems that are obstacles to the speed and accuracy of brand registration. Another goal is to find solutions to problems that are obstacles to the speed and accuracy of brand registration. This research is descriptive to provide a description of the problems that occur and the type of research is empirical legal research, namely from library research that is arranged systematically, researched, and studied in full. This research is very important so that the brand registration process can be accelerated, more accurately which can result in legal certainty and protection for brand registrants in carrying out their business. The results showed that: First, the brand registration process must use filtering at the first search stage and registration of a brand, about similarities with brands registered in the same or different classes in order to reduce the examiner's workload and the number of brand disputes that have been this is done when examining a registered trademark. Second, the obstacles found can be overcome with a complete database and the use of technological sophistication.
\end{abstract}

Keywords:

Registration, Brand, Trade Mark, Speed, Process, Legal Certainty 


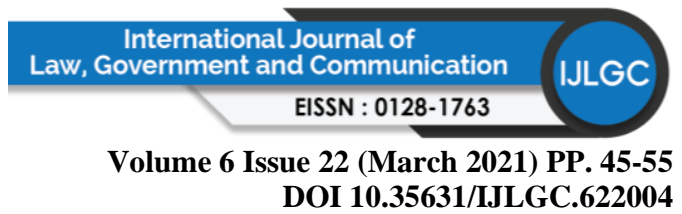

\section{Introduction}

Brand is a manifestation of intellectual works having important role for the smoothness and improvement of goods and services trades in trading and investment activities taking places in nowadays globalization development. Due to this important role of brands, brands are put in legal protection, i.e as an object against brands related to individual or legal entity rights.

Given the importance of registered brands, the fast brand registration process is very important so that the brand owner obtain legal certainty as soon as possible especially in this globalization and business competition era in which a brand is an identity of products being sold both in the form of goods and services as explained above. Because of the importance of brands to be registered, it leads to the enactment of Law Number 20 of 2016 concerning Brands and Geographical Indications in lieu of Law Number 15 of 2001 concerning Brands. The length of application process for brand registration as regulated in Law Number 20 of 2016 concerning Brands and Geographical Indications, which starts from the date of receipt until the issuance of a certificate of trademark takes about 7 (seven) to 9 (nine) months. Previously in Law Number 15 of 2001 concerning Brands, the application process for brand registration took about 12 (twelve) to 18 (eighteen) months. Thus, the enactment of Law Number 20 of 2016 concerning Brands and Geographical Indications is a new breakthrough for businesses world related to brand registration.

However, in the practice, it is difficult for Directorate General of Intellectual Property Rights (DJHKI) to meet the period of brand registration process in accordance with the provisions of the said law, mainly due to the high volume of applications compared to the examiners possessed by DJHKI. In general, one application usually will take between 18 to 24 months and frequently more than 24 months until the issuance of the Certificate. The length of brand registration processes can be seen from the following examples:

1. GT-PRO brand registered by Sambudi Ongko on December 15, 2006 under registration number D002006041056 had completed its registration process on June 25, 2014 with certificate number IDM 006415967 ;

2. GT-PRO brand registered by PT Garuda Top Plasindo on July 01, 2004 under registration number D062004018665 had completed its registration process on August 28, 2007 with certificate number IDM 000133561;

3. REMINGTONS brand registered by PT Spartadua Ribu Jaya on March 20, 2012 under registration number D002012831 had completed its registration process on November 10, 2007 with IDM certificate number IDM 000508126;

4. ESSENSIA brand registered by Ir. Yusuf Gunawan, SH, MH, MBL on July 20, 2010 under registration number R002009006456 had completed its registration process on January 18, 2013 with certificate number IDM 00381668 ;

5. RADIANT brand registered by PT Radiant Sentral Nutrindo on November 27, 2014 under registration number J002104054614 has completed its registration process on January 20, 2017;

6. NATURE HEALTH brand registered by PT Radiant Sentral Nutrindo on Tuesday, July 11, 2006 under registration number D002006022052 had completed its registration process on January 13, 2010 with certificate number IDM 000232566; 


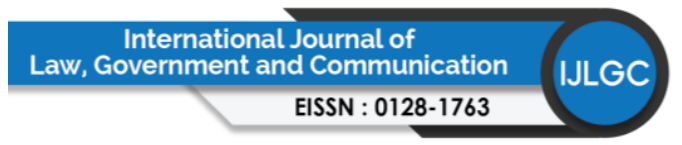

Volume 6 Issue 22 (March 2021) PP. 45-55

DOI 10.35631/IJLGC.622004

\section{Problem Statement}

From the examples above, it can also be stated that the process completion date does not necessarily mean that the brand certificate has been received. The brand certificate process takes approximately 3 months and often takes more than 1 year. It depends on the active role of brand registrants or Intellectual Property Rights Consultants (KHKI) to monitor when the brand certificate is issued and signed in the trademark office in Jakarta and it can be imagined if the registrant or IP Consultant is outside this city or outside the island. It spends many costs and time to take a brand certificate which the brand registration has been completed. This condition shows that the product of Law Number 20 of 2016 concerning Brands and Geographical Indications is not much different from the previous law concerning brands.

Procedurally, a brand registration process is the authority of Directorate General of Intellectual Property Rights and Intellectual Property Rights consultants as stipulated in the law concerning brands. Meanwhile, Intellectual Property Rights (IPR) Consultant as profession in the field of intellectual property rights which is officially registered at the Directorate General of Intellectual Property Rights, having authority based on the applicant's power of attorney and guiding the brand application from the start until the completion with a relatively faster processing time and relative affordable costs, he/she is no right to intervene and accelerate the IPR registration process,

\section{Results From Researches}

1. WEAKNESS OF LAW ON BRANDS IN TERM OF BRAND REGISTRATION (Study on the Verdict of Pierre Cardn Brand Dispute), author: Karlina Perdana karlinaprdn@yahoo.com, a student of Faculty of Law at Sebelas Maret University in Surakarta and Pujiyono pujifhuns@gmail.com, a Lecturer of Faculty of Law at Sebelas Maret University in Surakarta, published in the Law Journal of Adigama University, Private Law Vol. V No 2 July-December 2017. The writing of this law studies the weaknesses of Law Number 20 of 2016 concerning Brands and Geographical Indications given that until now there are still many imitating brands that have passed brand registration in Indonesia.

The conclusion of this study is that there is no brand philosophy requirement and it leads to multiple interpretations of understanding on well-known brands and the similar ones in the essence or in their entirety. It is found that the legal loopholes contained in the previous Law concerning Brands could not all improved in the new Law concerning Brands.

2. PASSING OFF IN BRAND REGISTRATION, Study on Supreme Court Decision Number 224 K/Pdt.Sus-HKI/2014, by Mieke Yustia Ayu Ratna Sari, Faculty of Law, Tulang Bawang University Jl. Gajahmada No. 34 Kotabaru Bandar Lampung 35121 Email: miekeius@gmail.com. Passing off is imitating actions against a well-known brand that may harm the holder of trademark rights. Such actions are carried out by dishonest business actors which often happen in trading practices, and therefore the enforcement of brand or trademark law shall obtain serious attention.

3. ANALYSIS ON THE STRENGTH OF GOOD FAITH ELEMENTS IN THE IMPLEMENTATION OF BRAND REGISTRATION IN INDONESIA (Case Study on Supreme Court Decision Number 364K/Pdt.Sus-HKI/2014) BASED ON LAW NUMBER 20 OF 2016 by Wilson Wijaya (Student of Bachelor (S1) Program, Faculty of Law, 


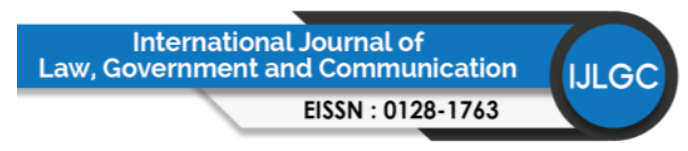

Volume 6 Issue 22 (March 2021) PP. 45-55

DOI 10.35631/IJLGC.622004

Tarumanagara University) (Email: wilsonsiwijaya@gmail.com) and Christine S.T. Kansil (Corresponding Author) (Lecturer of Intellectual Property Rights at the Faculty of Law, Tarumanagara University, Received a Title of Bachelor of Laws from the Faculty of Law, Tarumangara University, Master of Laws from the Faculty of Law, Tarumangara University) (Email: christinek 51170@yahoo.co.id). Brand is one part of intellectual property rights. Brand is an identifying mark that distinguishes one's property with another's property. However, there are many parties who have bad faith and want to be a part of other people brand's fame. The conclusion of this study is: There is no measure for determining the strength of good faith in the implementation of brand registration in Indonesia because each registrant is considered to have good faith to the extent all the requirements in the Trademark Law Number 20 of 2016 concerning Brands and Geographical Indications have been fulfilled. There is no reason for Directorate General of Intelectual Property (DJKI) to reject registrants who have fulfilled all the requirements set forth in Articles 4, 5 and 6. Thus, the strength of good faith element in brand registration is still very weak. There has been legal protection given to trademark owners provided by the government, however, it has not been effective because it is still limited to repressive protection. It is indeed difficult given that there are many parties who are still in difficulties to improve their brands into a well-known brands. Indeed, in this case, the government holds the responsibility for guaranteeing, upholding and enforcing human rights in relation to imitating someone else's trademark to seek for fame, but we must see other factors that cause the registration of other parties' brands, this other factor is the absence of special regulations concerning the protection of ordinary brands. It is due to the lack of legal awareness possessed by all society elements, because of the already created culture. Journal of Law of Adigama University, Vol 1, No 1 (2018).

4. Registering Disagreement: Registration in Modern American Trademark Law, article by Rebecca Tushnet. Harvard Law Review, Apr 4, 2019, Vol 130 Harv. L. Rev. 867. Trademark scholars widely agree that our current system for evaluating what rights a trademark owner should have over others' uses of their (or similar) marks is broken. The registration system is, and we should recognize it as such. It should not be left to collapse under its own contradictions.

5. A CRITICAL LOOK AT "USE"UNDER THELANHAMACTKrystil McDowall. The concept of "use" in trademark law is fundamental. However, many activities undertaken by a mark owner in connection with the trademark are not relevant uses for the purposes of obtaining and maintaining federal trademark registration. The regularity of federal cases litigating the use issue can be explained by the lack of a bright-line rule specifying what types of activity, and what quantum of use, will satisfy the use threshold. Without any change or development in the law, onecan expect that actions will continue to saturate the courts.By broadening and clarifying the use provision -including specifying that certain pre-sales activity constitutes use and loosening the quantum of use standard-Congress can keep countless lawsuits from the federal court system while strengthening the underlying spirit of the Act. New York University Journal Of Intellectual Property and Entertaiment Law, Volume 4, Spring 2015, Number 2. 


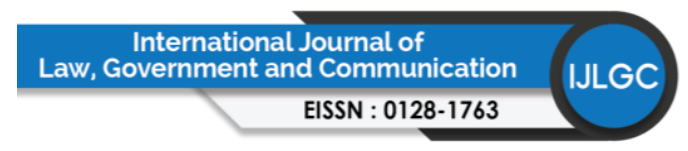

Volume 6 Issue 22 (March 2021) PP. 45-55

DOI 10.35631/IJLGC.622004

\section{Methodology}

Researches are basic means for developing knowledge because researches aim to reveal the truth systematically, methodologically and consistently. Systematically means using a particular system and consistently means there is no contradictory within a certain framework. Legal research is a scientific activity, which is based on certain methods, systematics and thinking, which aims to study one or several specific legal phenomena, by analyzing them;

Based on the problems studied by the Researcher, the research method used is normative and sociological or empirical legal research methods. Peter Mahmud Marzuki defines that normative legal research is a process to seek for a rule of law, legal principles and legal doctrines to resolve the legal issues being faced. Soerjono Soekanto said that normative or juridical normative legal research is a literature legal research conducted by studying literatures or secondary data. Meanwhile, sociological or empirical legal research, which includes research on legal identification and research on legal effectiveness.

Referring to the opinion above, the research approach that is relevant to this research is the one using the statute approach. The first phase of normative legal research is research aimed to obtain objective law (legal norms), namely by conducting research on legal issues. The second phase of normative legal research is research that must be aimed to obtain objective law (rights and obligations).

The reason why the researcher used statute approach is because statute approach is certain. It is certain because in legal logic, normative legal research is based on research conducted to the existing legal materials. Although, for example, the research is conducted because of the absence of legal vacuum, such legal vacuum can be known because of the existence of legal norms that require further regulation in positive law.

\section{Theoretical Basis}

\section{Legal Certainty}

It is common that certainty has become part of a law, written legal norms are preferred and prioritized. Law without certainty value will lose its identity and meaning, because it is no longer able to be used as a guide for everyone's behavior.

Certainty itself is essentially the main objective of law. Historically, many conversations have been made about laws since Montesquieu brought up an idea about power separation.

Public order is closely related to certainty in law, because order is the essence of certainty itself. Order will lead someone to live in certainty in carrying out activities required in people's lives. According to Sudikno Mertukusumo, legal certainty is a guarantee that the law will be implemented in a proper way.

Legal certainty demands the efforts of law regulation in a legislation which is made by the competent authorities, so that the rules have juridical aspects that can guarantee the certainty that law serves as a rule that must be obeyed. 


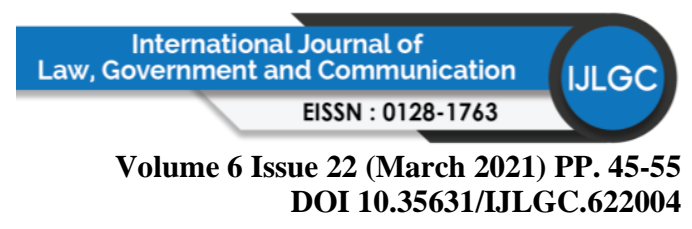

Lon Fuller in his book the Morality of Law proposes 8 (eight) principles that shall be fulfilled by law, which if not fulfilled, the law will fail to be referred as a law, or in other words there must be legal certainty. These eight principles are as follows:

a. A legal system shall consist of regulations, not based on deviating decisions for certain matters;

b. The regulation shall be announced to the public

c. It shall not be retroactive, because it will harm the system integrity;

d. It shall be made in a formulation that is publicly known;

e. There shall no conflicting regulations;

f. There shall no demand on action that exceeds what can be done;

g. It shall not be frequently changed;

h. There shall consistency between the regulation and the daily implementation.

Based on Lon Fuller's opinion above, it can be said that there shall be certainty between regulations and the implementation, thus, it has entered the action, behavior, and factors that influence how positive law is implemented.

\section{Legal Justice}

Justice can be defined as a value that is used to create a balanced relationship among people by giving a person's rights using procedures; and if there are violations related to justice then someone needs to be given a penalty.

The definition of justice according to the Big Indonesian Dictionary (KBBI) is an attitude that favors to the right, not favoritism or impartial. Justice is a demand for balanced attitude and nature between rights and obligations. One of the law principles that reflects justice is the principle of equality before the law i.e principle that states that all persons has equal position before the law.

The word justice has similarity with the word equity i.e fairness, which can be defined as follows (Munir Fuady, The Dynamics of Legal Theory, Ghalia Indonesia, Bogor, 2010, p. 91):

a. Justice, impartial, his due;

b. fair or equitable;

c. General principles about fairness and justice in the prevailing laws.

Aristotle (Greek philosopher) in his theory states that the measure of justice is (Munir Fuady, The Dynamics of Legal Theory, Ghalia Indonesia, Bogor, 2010, p. 93):

a. One does not violate the prevailing law, so that justice means lawfull, i.e the law shall not be violated and rules of law shall be followed;

b. One shall not take anything more than his rights, thus, justice means equal rights.

Aristotle in his book Ethics, divides justice into two groups namely (Munir Fuady, The Dynamics of Legal Theory, Ghalia Indonesia, Bogor, 2010, p. 109):

a. Distributive justice, i.e the balance between what he gets and what he deserves.

b. Corrective justice, i.e justice aimed to correct unjust events, as a form of equality between what he gives and what he gets.

Corrective justice as a form of justice is enforced through a legal process aimed to correct an unjust situation that has occurred, for example, criminal conviction in a criminal case. 


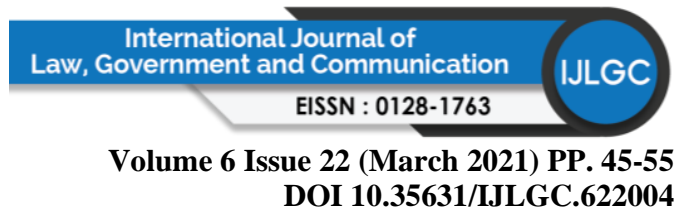

Justice can be defined as a value that is used to create a balanced relationship among people by giving a person's rights using procedures; and if there are violations related to justice then someone needs to be given a penalty.

Justice is the fulfillment of individual desires in a certain level. The greatest justice is the fulfillment of desires of as many people as possible. The fulfillment of justice so that a situation is worth to be called fair is a difficult thing. It cannot be answered based on rational knowledge. The answer to that question is a justification of value. (Jimly Asshiddiqie, Hans Kelsen's Theory of Law, Secretariat General of the Constitutional Court, Jakarta, 2006, p. 18).

In everyday life, we often hear a statement "you must do what is right and must not do what is wrong." But what does "right" and "wrong" mean? The answer to that question is given by positive law. They want to express the positive legal system as something just, although it is possible that a positive rule of law may not be just.

Justice can only arise based on positive law provision in the form of acts determined objectively. These rules are positive law. This can be the object of science, not law metaphysically. This theory is called the pure theory of law which presents the law as it is without maintaning to call it fair, or rejecting to call it unfair. This theory looks for real and obvious laws, not true laws (Jimly Asshiddiqie, Hans Kelsen's Theory of Law, Secretariat General of the Constitutional Court, Jakarta, 2006, p. 22)

\section{Effectiveness of Law}

Quoting the Administrative Encyclopedia, it conveys an understanding on effectiveness as follows:

"Effectiveness is a state that contains an understanding about the occurrence of the desired an effect, if one does an action with a specific purpose as desired. A person is said to be effective if he causes or has the intention as desired."

From the above definition, it can be concluded that a matter can be said to be effective if it is as desired. It means that the achievement of the desired thing is the achievement of the goals for the actions to achieve this. Effectiveness can be defined as a process to achieve a predetermined goal. An effort or activity can be said to be effective if such effort or activity has achieved its goals. If the intended goal is an agency's goal, then, process for achieving such goal is the success in carrying out its programs or activities according to the authority, duties and functions of that agency.

When we see the effectiveness in the field of law, Achmad Ali argued that when we want to know the extent of the law effectiveness, then we must first be able to measure "the extent to which the rule of law is obeyed or not obeyed". In further, Achmad Ali stated that in general the factors that mostly influence the effectiveness of a law are the professional and optimal implementation of the roles, authorities and functions of law enforcers, both in explaining the duties assigned to them and in enforcing these laws.

The law effectiveness theory according to Soerjono Soekanto is that the effectiveness of law is determined by 5 (five) factors, namely:

a. The legal factor itself (the law);

b. Law enforcement factor, namely those who establish and apply the law; 


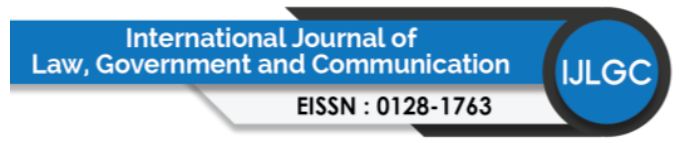

Volume 6 Issue 22 (March 2021) PP. 45-55

DOI 10.35631/IJLGC.622004

c. facilities factor that support law enforcement;

d. Community factor, namely the environment in which the law applies or is applied;

e. Cultural factors.

\section{Results And Discussion}

In the globalization era, technological jumps cannot be avoided and shall be utilized so that all processes can be accelerated, shortened, simple, precise and cheap. The role of Information Technology (IT) in the brand registration process is performed in the phase of brand checking, registration, checking until the issuance of brand certificate.

If the role of IT is implemented to accelerate the brand registration process, it is necessary to change the procedure from the brand checking process of to the issuance of registered brand certificate. As a result, the Law concerning Brands and Geographical Indications needs to be revised as well.

When checking a brand online, computer will check in the data base whether the brand to be registered can be registered or rejected and an answer will immediately be obtained. If a brand can be registered, the next process is the payment for the brand order according to the law and it is continued by submitting all necessary data and documents as proof of the registered brand ownership. The checking process should be eliminated because it has been taken over by computer system so that the brand certificate could be printed immediately. The brand announcement process can be eliminated because the registered brands have been checked by computer and it is not the same as the registered brands.

The provisions of Law on Brands and Geographical Indications that need to be changed are:

1. Priority Rights: shall be eliminated, all applicants have the same position before the law, this matter is associated with the principle of justice in law and none shall be prioritized. Therefore, Law No. 20/2016 concerning Brands in Part Two, concerning Application for Registration of Brands with Priority Rights in Article 9, reads: "Applications using priority rights must be submitted no later than 6 (six) months from the Date of Receipt of the Application for the Brand registration that is first received in another country that is a member of Paris Convention for the Protection of Industrial Property or a member of Agreement Establishing the World Trade Organization." And article 10 is also automatically deleted;

2. Well-known brand: the term well-known trademark shall be eliminated because all brands have the same position and it must not be distinguished between well-known brands and unwell-known brands that have been or newly registered because it is in contrary to the principle of justice. Article 21 paragraph $1 \mathrm{~b}$ and c, states that, "(1) An application is rejected if a Brand has similarities in principle or in the entirety with:

a) A registered brand that belongs to another party or has been registered in advance by another party for similar goods and/or services;

b) Other parties' well-known brands for similar goods and/or services;

c) Other parties' well-known brands for non-similar goods and/or services fulfilling certain requirements;

d) Similarity/Resemblance Principle: All brands have the same position, thus, similar or resembling brands are different and not the same brands. It is to anticipate that 


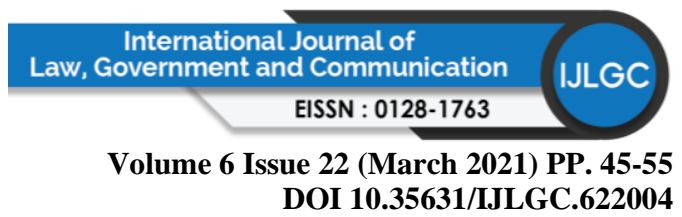

in the future there will be more and more brands be registered. It is as stated in Article 21, which reads: "An application is rejected if the Brand has similarities in the essence or in the entirety with:..." Amended into, "An application is rejected if the Brand has similarities in the entirety with: ..."

e) Process flow: If both provisions above are changed and the role of IT is applied, the flow of the brand registration process will be simpler, shorter, cheaper and it will avoid brand disputes;

f) Handover of brand certificates: the handover of brand certificate will be simple and fast in which the brand consultant or registrant does not need to take the brand certificate to the Director General of Intellectual Property Rights in Jakarta or the Director of Brand does not need to send a notice to take the brand certificate, the registrant can print the brand certificate himself. Likewise, everyone can see the brand ownership data because it can be accessed online. Article 25 Paragraph 3 states that: "In the event that an issued Brand certificate is not been taken by the Brand Owner or his Proxy for a maximum period of 18 (eighteen) months from the date of issuance of the brand certificate, the Brand that has been registered are deemed to be withdrawn and deleted." It is amended into, "Brand certificates are issued electronically and can be downloaded and printed at any time by the brand registrants or their proxies and they are official proof of brand ownership."

\section{Conclusion}

From the explanation above, according to legal certainty theory, justice and effectiveness theory, then, Law concerning Brand No. 60 of 2016 needs to be revised namely about:

1. Procedures for brand registration processes need to be changed from brand checking to the issuance of brand certificates in which brand checking is a guarantee of legal certainty that such brand can be registered and the brand certificate is guaranteed to be issued quickly.

2. For the justice for registrants and brand owners, Law No. 20 of 2016 concerning Brands and Geographical Indications needs to be amended, namely:

a) Article 9 which regulates priority rights should be eliminated

b) Article 21 paragraphs $1 \mathrm{a}$ and $\mathrm{b}$ that regulate well-known brands should be eliminated;

c) Article 21 which regulates brands which have similarities in the essence and in its entirety should be amended into having similarities in its entirety;

d) Article 25 paragraph 3 which regulates the handover of certificates from manual to electronic.

3. The function of brand checking is eliminated because it has been taken over by computer technology, thus, the objection and refusal process of brand registration will no longer exist.

4. The brand announcement process should be removed and replaced by the announcement of newly registered brands.

5. The function of Brand Appeals Commission is temporary because it only works when a brand passes brand checking by computer because the existing database is not updated. 


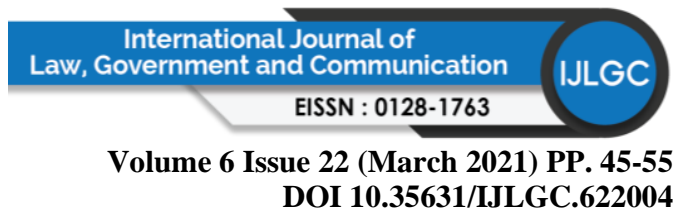

6. With the change in brand registration procedures and with the use of information technology, it will realize the efficiency and effectiveness of brand registration process which means that the registration process becomes very fast, simple and inexpensive in accordance with the spirit of reform and the time demands.

\section{References}

\section{Books:}

Abdulkadir Muhammad, Hukum Perusahaan Indonesia, Citra Aditya Bakti, Bandung, 2010. Andrian Sutedi, Hak atas Kekayaan Intelektual, Sinar Grafika, Jakarta, 2009.

Arifin Abdul Rachman, Administrasi Pemerintahan Dalam Pembangunan, CV. Haji Mas Agung. Jakarta, 2002.

Budi Agus Riswandi, Aspek Hukum Internet Banking, Raja Grafindo Persada, Jakarta, 2005.

Burhan Bungin, Metodologi Penelitian Kualitatif : Aktualisasi Metodologi Ke Arah Ragam Varian Kontemporer, PT. Raja Grafindo, Jakarta, 2007.

Dwi Rezki Sri Astarini, Penghapusan Merek Terdaftar, Alumni, Bandung, 2009.

Joko Widodo, Good Governance, Telaah dari Dimensi Akuntabilitas dan Kontrol Birokrasi Pada Era Desentralisasi dan Otonomi Daerah. Insan Cendekia, Surabaya, 2001.

Lawrence M, Friedman, Law and Society An Introduction, Prentice Hall Inc, New Jersey, 1977. OK. Sadikin, Aspek Hukum Hak Kekayaan Intelektual (Intellectual Property Right), Cetakan 4, Raja Grafindo Persada, Jakarta, 2004.

Paserangi, Hak Kekayaan Intelektual, Perlindungan Hukum Hak Cipta Perangkat Lunak Program Komputer Dalam Hubungannya Dengan Prinsip-Prinsip Dalam TRIPs Di Indonesia, Jakarta, Rabbani Press, 2011.

Peter Mahmud Marzuki, Pengantar Ilmu Hukum, Kencana, Jakarta, 2008. Penelitian Hukum, Kencana Prenada Media Group, Jakarta, 2010.

Rahmi Jened, Hukum Merek (Trademark Law) Dalam Era Global \& Integrasi Ekonomi, Kharisma Putra Utama, Jakarta, 2015.

Riduan Syahrani, Rangkuman Intisari Ilmu Hukum, Citra Aditya, Bandung, 1999.

Stoner, S., James A.F., Edward Freeman and Gilbert, Daniel, Management, Prentice Hall inc, New Jersey, 2005.

Margono dan Amir Angkasa, Komersialisasi Aset Komersial Aspek Hukum Bisnis, Gramedia Widiasarana Indonesia, Jakarta, 2002.

Mukti Fajar dan Yulianto Achmad, Dualisme Penelitian Hukum Normatif Dan Empiris, Pustaka Pelajar, Yogyakarta, 2010.

Soerjono Soekanto, Faktor-Faktor Yang Mempengaruhi Penegeakan Hukum, Cetakan Kelima, Raja Grafindo Persada, Jakarta, 2004.

, Pengantar Penelitian Hukum, cetakan III, UI Press, Jakarta, 2007. , Pengantar Penelitian Hukum, UI Press, Jakarta, 1981.

Soerjono Soekanto dan Sri Mamudji, Penelitian Hukum Normatif, Suatu Tinjauan Singkat, Raja Grafindo Persada, Jakarta, 2011.

Sugiyono, Metode Penelitian Kuantitatif Kualitatif dan R\&D, Alfabeta, Bandung.

Suyud Margono, Hak Milik Industri: Pengaturan dan Praktik di Indonesia, Ghalia Indonesia, Bogor, 2011.

\section{Constitution:}

Undang-Undang Nomor 15 tahun 2001 tentang merek.

Undang-Undang Nomor 20 tahun 2016 tentang merek dan Indikasi Geografis. 
Volume 6 Issue 22 (March 2021) PP. 45-55

DOI 10.35631/IJLGC.622004

Peraturan Menteri Hukum dan Hak Asasi Manusia (Permenkumham) Nomor 67 Tahun 2016 tentang Pendaftaran Merek.

\section{Internet:}

Patendo (Konsultan HKI Terdaftar), Permasalahan Pendaftaran Merek di Ditjen HKI, https://mendaftarkanmerekdagang.com/ditjen-hki/, diunduh tanggal 15 Januari 2019.

http://startuphki.com, Dilema Proses Pendaftaran Merek yang Sangat Lama dan Penyuapan, 30 Mei, 2015. Diunduh pada tanggal 15 Januari 2019.

http://etd.repository.ugm.ac.id/index.php?mod=penelitian_detail\&sub=PenelitianDetail\&act= view\&typ=html\&buku_id=163031\&is_local=1

http://scholar.unand.ac.id/28962/. Diunduh pada tanggal 16 Januari 2019.

http://www.lib.ui.ac.id/file?file=pdf/abstrak/id_abstrak-20306760.pdf. Diunduh pada tanggal 16 Januari 2019.

http://repository.uinsu.ac.id/3785/1/Disertasi\%20Revisi\%2012-09-2017.pdf. Diunduh pada tanggal 16 Januari 2019. 